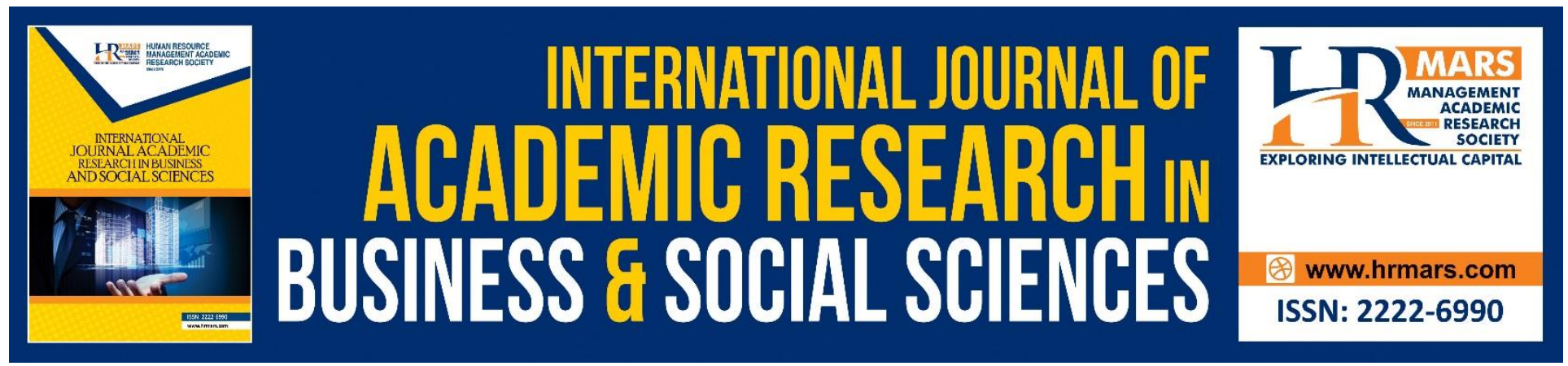

\title{
AsKINstagram: Teacher-Pupil Interaction
}

\author{
Ani Mardhiah Jalaludin, Nurul Ain Abas, Melor Md Yunus
}

To Link this Article: http://dx.doi.org/10.6007/IJARBSS/v9-i1/5369

DOI: $\quad 10.6007 /$ IJARBSS/v9-i1/5369

Received: 19 Dec 2018, Revised: 26 Dec 2018, Accepted: 17 Jan 2019

Published Online: 28 Jan 2019

In-Text Citation: (Jalaludin, Abas, \& Yunus, 2019)

To Cite this Article: Jalaludin, A. M., Abas, N. A., \& Yunus, M. M. (2019). AsKINstagram: Teacher-Pupil Interaction. International Journal of Academic Research in Business and Social Sciences, 9(1), 125-136.

\section{Copyright: (c) 2019 The Author(s)}

Published by Human Resource Management Academic Research Society (www.hrmars.com)

This article is published under the Creative Commons Attribution (CC BY 4.0) license. Anyone may reproduce, distribute, translate and create derivative works of this article (for both commercial and non-commercial purposes), subject to full attribution to the original publication and authors. The full terms of this license may be seen at: http://creativecommons.org/licences/by/4.0/legalcode

Vol. 9, No. 1, 2019, Pg. 125 - 136

Full Terms \& Conditions of access and use can be found at http://hrmars.com/index.php/pages/detail/publication-ethics 


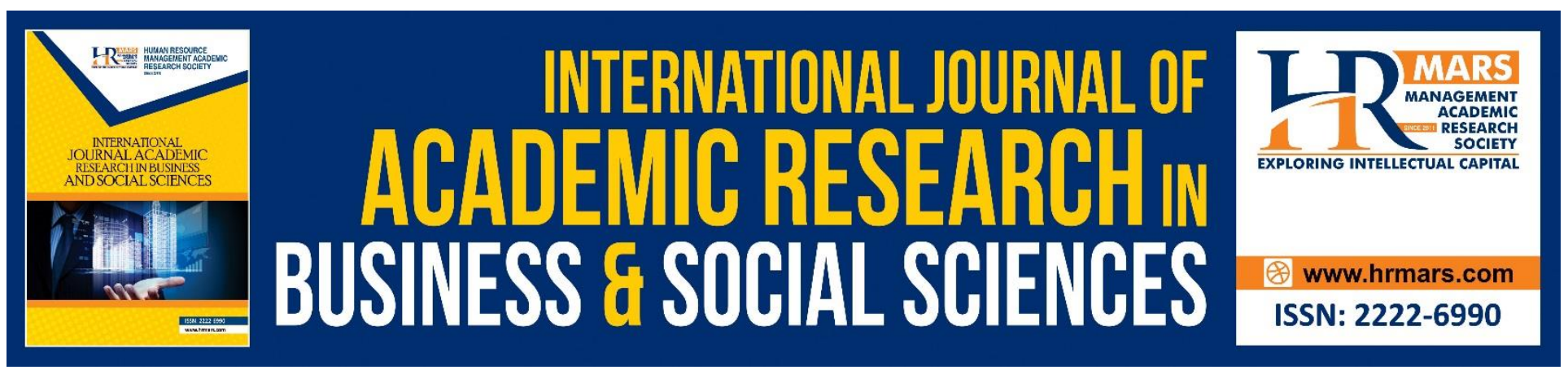

\title{
AsKINstagram: Teacher-Pupil Interaction
}

\author{
Ani Mardhiah Jalaludin ${ }^{1,2}$, Nurul Ain Abas ${ }^{2}$, Melor Md Yunus ${ }^{2}$ \\ ${ }^{1}$ Sekolah Kebangsaan Pantai Kundor, Melaka, ${ }^{2}$ Faculty of Education, Universiti Kebangsaan \\ Malaysia \\ Email: animardhiah@gmail.com, ciknaa86@gmail.com
}

\begin{abstract}
Social media promotes a conducive learning where teachers and pupils remain engaged after school hours. There is a need in integrating social network, Instagram in language learning. The innovation is named "AsKINstagram" as it was merely limited to the use of ASK feature in Instagram to serve as a platform for teachers to assess pupils' performance in writing in English. Not to mention that it intends to engage parents to support the virtual learning as well. The study was conducted in six sessions on a group of 24 Year 5 and Year 6 pupils of SK Pantai Kundor, Melaka. The data was analysed based on pupils' performance before and after the innovation and a Likert-scale questionnaire is conducted to survey the pupils' and parents' feedback. The results indicate that there is improvement in students' writing as "AsKINstagram" does not only provide conducive learning for students to learn English after school hours but also enticing parents to learn together with their kids.
\end{abstract}

Keywords: English Language Writing, Instagram, Mobile Learning, Social Media

\section{INTRODUCTION}

Social media do not only serve as a medium of instruction, but they do promote and celebrate learning by allowing students and teachers to experience learning in a new and exciting ways (Mansor, 2016). Teachers can reach their students through social media like Facebook, Blogs, Instagram, email and Twitter which serve as platforms for students to collaboratively involve in the dialogue, exchange ideas and find answers to questions. It is supported by some studies that found the media technology helps in the process of learning (Lunden, 2014; Normaliza Abdul Rahim, 2014; Fritta Faulina Simatupang, 2015). The studies are profound pertaining to the issues in language learning focusing on the four skills; speaking, writing, reading and most importantly writing.

According to Alsamadani (2010) and Adas \& Bakir (2013), of all the four skills, writing is more challenging and intricate than speaking as students who learn English as a Second Language (ESL) and English as a Foreign Language (EFL) need to acquire more aspects in term of handwriting, spelling, coherence, punctuations and ideas. It is proven from the study by Fadda (2012) which stated that ESL students faced difficulties when they needed to sit for writing tests. Therefore, teaching writing to ESL and EFL need to be celebrated with the integration of ICT as it will motivate students to learn 
writing independently while searching for materials online as students could adapt the materials to help them in the process of writing (Melor et al, 2013). Besides, according to Warnock (2009) teaching writing virtually also can be purely textual, thus promote the opportunity for students to practice their writing skills. The integration of ICT and media social which is now available in mobile application as tools to assist teaching has been seen as a jumpstart to alleviate students' motivation in ESL writing through prominent social media like Facebook, Instagram, Twitter, Blogs and email. It is supported by Hashim, Yunus, and Embi (2018) stating that the mobility characteristic of mobile devices let students to practise the learning everywhere and anytime which also support this study who seeks to promote learning beyond the classroom contexts.

Mobile applications like Facebook, Twitter, WeChat and Instagram become paramount in education as it delineates the new and exciting ways students and teachers would experience when they use social media apps through their smartphones to interact (Mansor, 2016). According to Lunden (2014), comparing between Facebook and Instagram, the latter is proven to be popular the quickest. It is supported by Vie (2008) stating that young learners now are fully immersed with Instagram as a language learning tool where they can apply what they have learned in school in reality. Not to mention that students' familiarity with Instagram is seen as a tool to promote simple and exciting learning activities (McBride, 2009). More studies come into play where Instagram is incorporated in the learning innovation (Wiktor, 2012; Bell, 2013; Solomon, 2013; Tekulve \& Kelly, 2013; Al-Ali; 2014; Lunden, 2014; Pero Ali, 2014; Fritta Faulina Simatupang, 2015; Khalitova \& Gimaletdinova, 2016; Akhiar et al, 2017; Mansor \& Rahim, 2017).

Since Instagram is gaining the popularity among students and teachers, this study is focusing on one of its emergent feature namely ASK feature to facilitate learning beyond classroom contexts. The mobile application Instagram focusing on its ASK feature was selected as a tool for this study due to its growing popularity as of June 2018 , there are nearly 1 billion monthly active users and 500 million daily active users (https://adespresso.com/blog/instagram-statistics/) besides the emergence of recent interactive ASK feature which serves as a medium to ask and to respond is good and will benefit both teachers and modern students. Therefore, this study sought to answer the following research questions:

1. Is there any significant improvement in pupils' performance in writing in English towards the integration of ASK feature in Instagram?

2. Does the integration of ASK feature in Instagram maximize pupils' participation in writing in English?

3. Does the integration of ASK feature in Instagram motivate pupils to learn writing beyond the classroom context?

\section{THE USAGE OF INSTAGRAM IN EDUCATION}

Studies on social media in ESL classroom have been widely and emergently carried out worldwide. The studies include the application of mobile applications like Facebook, Blogs, Twitter and Instagram through smartphones. As Instagram has gained its popularity, more research has been done to bring 
this mobile application forward as a tool that can help to motivate the learning process. Wiktor (2012) stated that Instagram benefits learners with special intelligence (mental process in interpreting information through pictures, maps, plans etc) and linguistic intelligence. It is depicted through students' feedback when they are asked to comment on teachers' posts which encourage them to apply their language skills. Therefore, Wiktor (2012) explores students' multitasking using smartphones and their interaction with their peers based on the task given. It is conducted on 20 students of Business Communication Course at Universiti Malaysia Terengganu. The focus of this study is on students' communication skills through mobile learning and also the limitations of using Instagram in ESL classroom.

\section{THE BENEFITS OF USING INSTAGRAM IN ENGLISH LANGUAGE LEARNING}

Bell (2013) also carried out similar study using Instagram and claimed that it enriches the communication skills through expressing ideas and feelings in their captions in Instagram. This written communication helps boost students' self-esteem and confidence. It is supported by Salomon (2013) who agreed that Instagram does not only entice people, but also helps students enhance their confidence online. It is further clarified by Mansor \& Rahim (2016) who agreed with Bell (2013) and Salomon (2013) and disclosed that students have built their confidence in writing through Instagram interactions.

Lunden (2014) and Fritta Faulina Simatupang (2015) have incorporated the Instagram in their studies and concluded social media have helped in the process of learning. It is equivalent with the study done by Al-Ali (2014) who claimed that ESL classroom can be successful with the integration of Instagram. Al-Ali (2014) focuses on the holiday project programme that requires students to upload pictures and together with captions written. The results showed that there is progressive growth in students' interest in welcoming the idea during the process of writing their activities. Bell (2013) study was similar to the study of Al-Ali (2014) where the expressions of ideas and feelings through Instagram captions has enhanced the learning. Furthermore, Pero Ali (2014) exposed that Instagram celebrates the learning by having such incredible features besides gradually becoming one of the most popular social media applications.

Khalitova \& Gimaletdinova (2016) conducted a case study on integrating Instagram in teaching English as a foreign language (EFL) with advanced level students $(N=50)$ in Kazan Federal University, Russia. The study seeks for students' perception on mobile assisted language learning (MALL) in relation to the educational value besides how far Instagram could improve students' listening skills. Apart from listening, other researchers like Akhiar et al (2017) have carried out a study to find out students' perceptions and attitudes in English language writing through Instagram. The results revealed that students showed positive perceptions towards the integration of Instagram in improving their writing skills but only having moderate attitudes. Meanwhile, a study conducted by Mansor \& Rahim (2017) reveals students' experience in using Instagram with their peers. Not only students' participation in online discussions is investigated, but also their feedback on the use of Instagram as a tool to enhance the learning. The results showed a great significance of Instagram as a tool to generate students' participations in classroom activities. The students became the subjects involved seemed to be more inspired feel encouraged to participate in the learning. 
In term of theories related to language learning using social media, Gilakjani et al (2013) stated that Constructivism theory and Collaborative theory are involved. Constructivism promotes independent learning where teachers act as instructors to encourage students from being passive to actively involve to seek for knowledge. The environment must be conducive and suitable for the learning process, therefore, mobile devices could give exposure for students to be embedded in real context. Meanwhile, it also promotes collaborative theory where students can interact with peers or with teachers. A lot of new approaches about learning were developed in the 1990s and most are engrained from Vygotsky's socio-cultural psychology.

\section{METHODOLOGY}

The participants of this action research were a group of 24 Year 5 and Year 6 pupils of SK Pantai Kundor, Melaka. They consisted of 13 Year 5 pupils and 11 Year 6 pupils, 7 boys and 17 girls. All of them or their family members have smartphones, Internet access and own Instagram accounts as the requirement for this study. The study was quantitatively and qualitatively conducted through surveys, pre-tests and post-tests and open-ended interview to support the findings. An information letter together with consent form was given to the parents to inform about their children's involvement as the participants in this study and to ask the parents to monitor the children during answering the questions in "AsKINstagram". The letter also includes clarification that the information provided by the participants will be used only for the study and assurance that the confidentiality of their responses and the data collected will not be provided to anyone without permission. All the participants' parents agreed and permitted for their children to be involved.

The process of data collection is carried out as in the following Figure 1. It began with the questionnaire consisting of 10 Likert-scale questions for the pupils about their perceptions on Instagram. Then the pre-test on Topic 1 was carried out before lessons were conducted. This is to determine the participants' levels so that the teacher can provide suitable instructions for the topic. After that, 3 sessions of "AsKINstagram" were conducted based on the previous lesson, Topic 1 . The step-by-step of "AsKINstagram" session were carried out as shown in Figure 2. After the three "AsKINstagram" sessions had been done, post-test on Topic 1 was carried out to determine how far pupils had understood the lesson. The cycle of pre-test, lesson, "AsKINstagram" and post-test were repeated for Topic 2. After that, another two separate surveys of 5 Likert-scale questions were carried out to the participants and their parents respectively to get their feedbacks on their perceptions towards the integration of ASK feature in Instagram in language learning. At the end, open-ended interview of 2 questions was conducted on 10 randomly selected participants to seek in-depth understanding about their engagement with "AsKINstagram". 
INTERNATIONAL JOURNAL OF ACADEMIC RESEARCH IN BUSINESS AND SOCIAL SCIENCES Vol. 9, No. 1, Jan, 2019, E-ISSN: 2222-6990 @ 2019 HRMARS

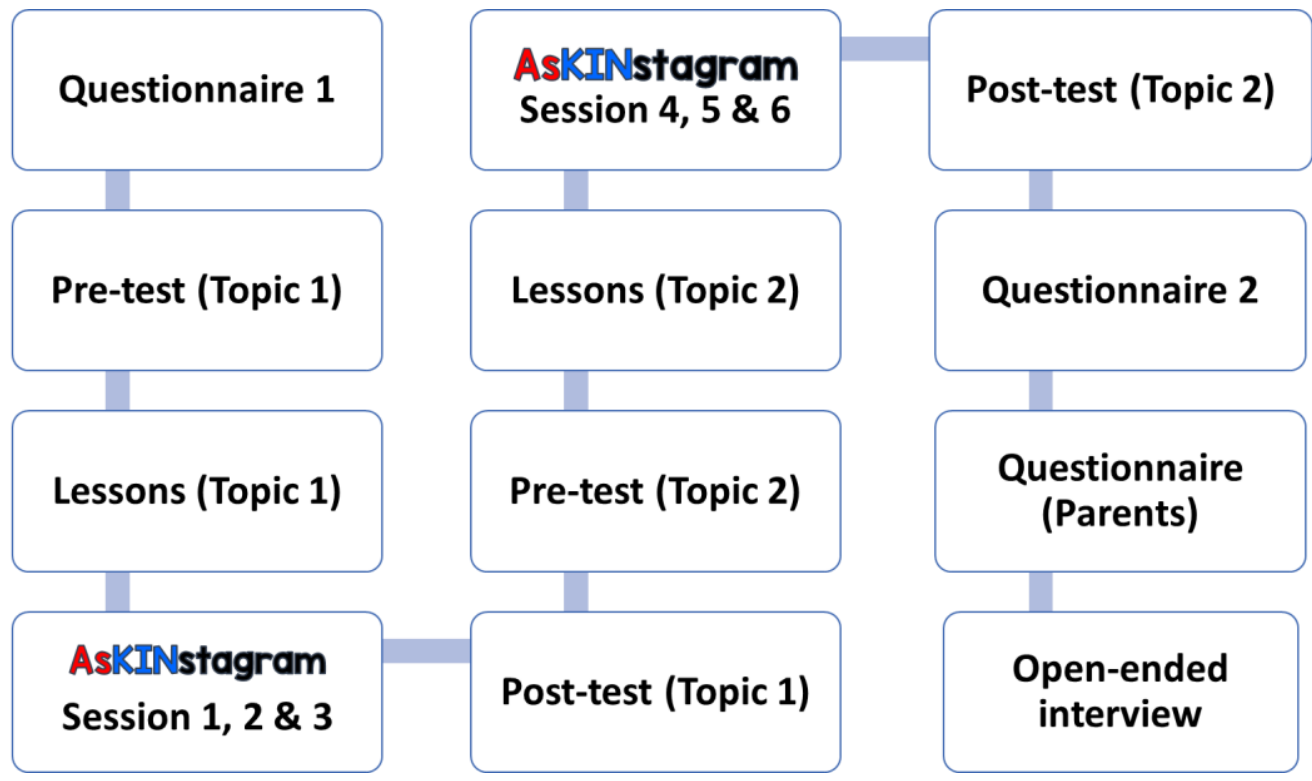

Figure 1 : The process of data collection

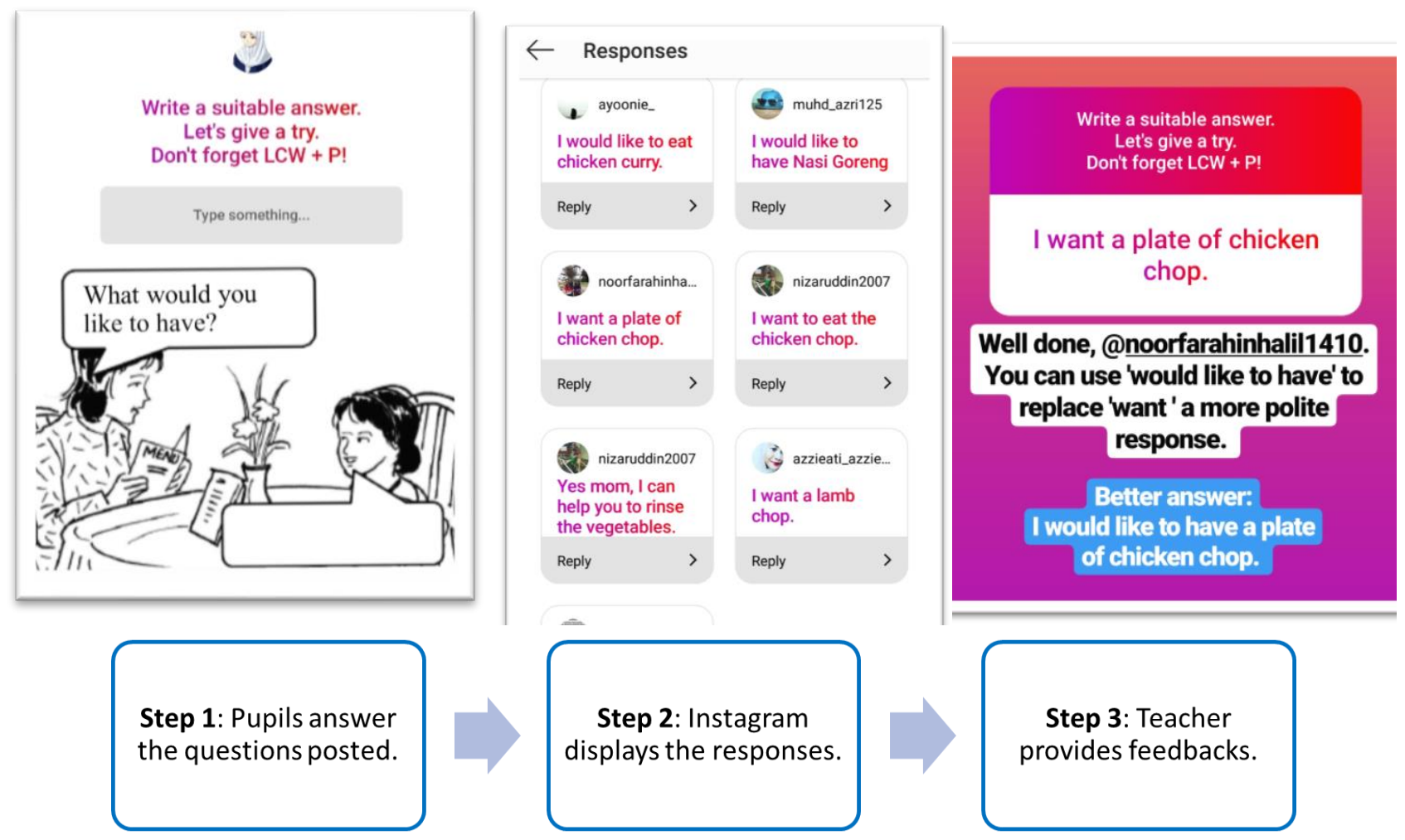

Figure 2 : Step-by-step of “AsKINstagram" 
INTERNATIONAL JOURNAL OF ACADEMIC RESEARCH IN BUSINESS AND SOCIAL SCIENCES

Vol. 9, No. 1, Jan, 2019, E-ISSN: 2222-6990 @ 2019 HRMARS

All the data collected from the surveys, pre-tests, "AsKINstagram" sessions and post-tests were recorded in Microsoft Excel 2016 and the data from interview were transcribed in Microsoft Word 2016. The data used for this study was analysed using Statistical Package for the Social Sciences (SPSS) version 23 and the graph was generated using Microsoft Excel 2016.

\section{FINDINGS AND DISCUSSIONS}

This study examined the effects of an innovation of integrating social network, ASK feature in Instagram named as "AsKINstagram" in language learning, targeting the writing skill. To get to know the participants' perceptions regarding learning writing through Instagram, a questionnaire was given before the pre-test was conducted and the responses was collected and recorded. From the data, most of them did not engage in learning English after the school hours and they also perceived writing in English as a difficult skill to master. Besides that, majority of them were not aware that they could learn English through Instagram. Nevertheless, all of them were enthusiastic to learn the writing skill in English with their teacher through Instagram.

Apparently, the participants are the generation alpha who are digital natives, so learning writing through Instagram are viewed as interesting, enjoyable and engaging. At the end of the six sessions of "AsKINstagram", they responded that the ASK feature in Instagram is user-friendly and they had no difficulties of using it. This is supported by Yunus, Salehi, and Chenzi (2012) who pointed out that Social Networking Services (SNSs) display material in a way that promote familiarity and comfort to the digital natives and "engage" them in using SNS. Although initially quite several participants were unfamiliar with Instagram as a mobile learning tool, they found that that towards the end, the ASK feature in Instagram helps them in learning English.

The data in the following Figure 2 was gathered and recorded from the pupils' participations during all six sessions of "AsKINstagram". As of the first session, only $20.80 \%$ of the participants answered the questions but it increased up progressively to $61.60 \%$ on the last session. It demonstrates that although the pupils were not enthusiastic with "AsKINstagram" initially, they gradually welcomed the innovation and were motivated to participate in answering the questions posted. From the second questionnaire and open-ended interview conducted with the participants, some of them responded that at first, they were anxious to answer the questions and felt inferior with other participants' answers. However, when they saw how the teacher gave feedbacks and others responded, they felt less inferior and excited to see their answers were given feedbacks and posted in the story in Instagram. This same situation was also experienced by the students in the studies conducted using Instagram in language learning by Al-Ali (2014) and Mansor and Rahim (2017) whereby a number of students hesitated to post their answers and participate in the task given in Instagram but this number had decreased towards the end of the studies. Mansor and Rahim (2017) pointed out that the students in their study claimed that using Instagram as learning tool for English has motivated them to participate and boosted their confidence to use the language. 
INTERNATIONAL JOURNAL OF ACADEMIC RESEARCH IN BUSINESS AND SOCIAL SCIENCES Vol. 9, No. 1, Jan, 2019, E-ISSN: 2222-6990 @ 2019 HRMARS

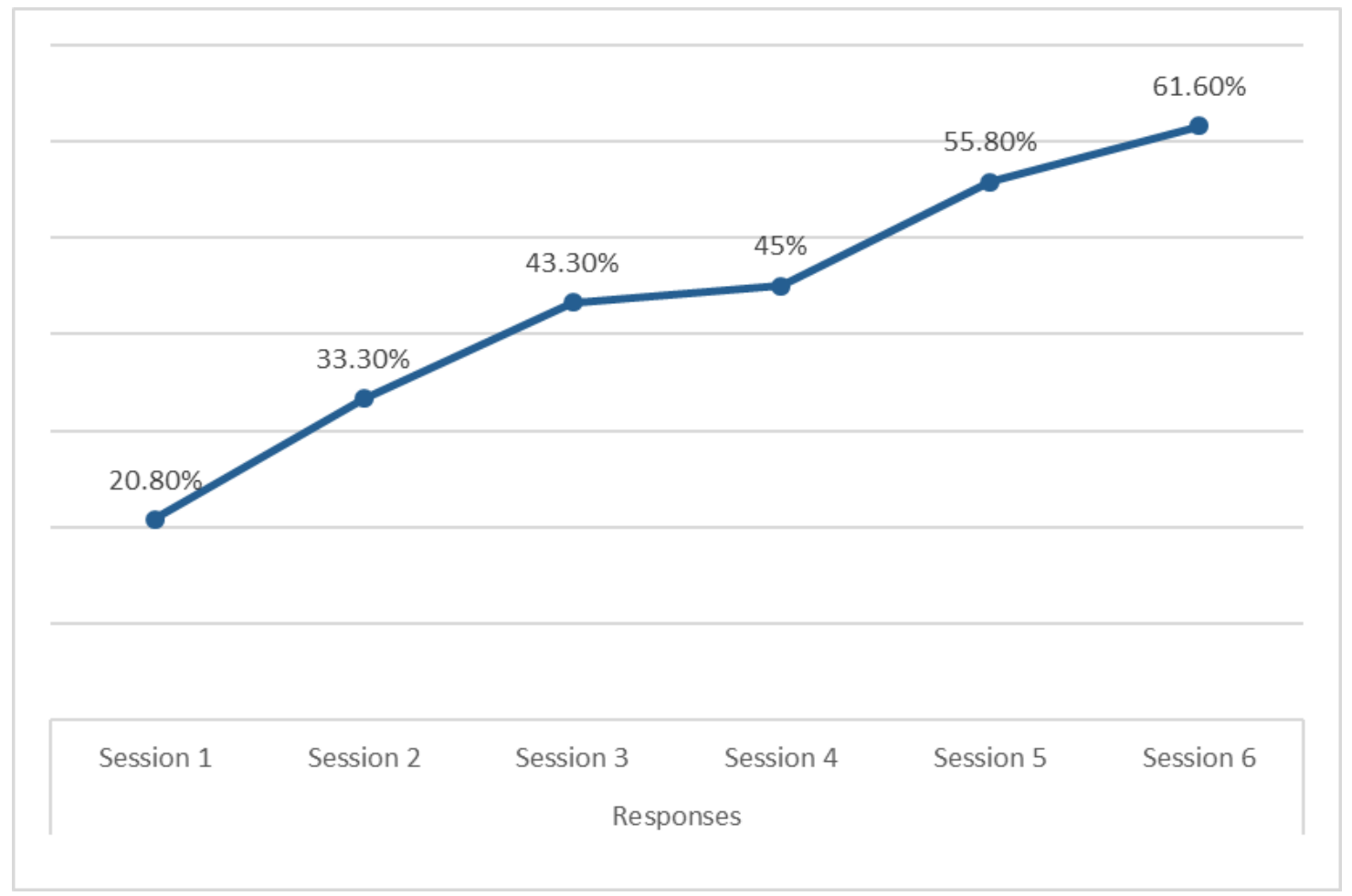

Figure 2: Percentage of Participation

Besides that, the number of participation is increased because of the feature of mobile learning that extends the participants' learning environment beyond their classroom setting. Most of them agreed that mobile learning promotes the autonomous learning since they can have access to Instagram and answer the questions posted by teacher anytime and anywhere. This is supported by Bidin and Ziden (2013), Yedla (2013) and Zaki and Yunus (2015) that the flexibility of mobile learning for learners encourage them to learn conveniently without the presence of teacher and lead to both self-directed and self-regulated learning. Hashim et al. (2018) also agreed that mobile learning creates a "mobile learning environment" which enables learners to have autonomy to "practise learning anytime, anywhere" and at the same time "maintains contact" between the learners and teachers outside the classroom.

Another benefit of mobile learning is the easy accessibility enriches the learners' learning experience and makes learning English become easier and faster (Mansor, 2016; Yedla, 2013). The participants stated that learning through mobile allows them to refer to the notes posted by teacher in Instagram and search for further reference in the Internet simultaneously while they were answering the "AsKINstagram". It makes them have more confidence with their answers and feel motivated to engage in the writing tasks assigned. This is in line with the claim made by Yunus, Nordin, Salehi, Sun, and Embi (2013) that the integration of ICT benefits the writing instruction since it enhances the "learners' independence and self-discovery skills like searching for educational related materials online". It also provides a platform for them to connect and communicate with their friends and teacher regarding the task. During "AsKINstagram", the participants interacted with teacher and their friends to ask for clarification of unclear instructions before answering the questions posted or 
INTERNATIONAL JOURNAL OF ACADEMIC RESEARCH IN BUSINESS AND SOCIAL SCIENCES

Vol. 9, No. 1, Jan, 2019, E-ISSN: 2222-6990 @ 2019 HRMARS

further explanation related to the topics. Akhiar, Mydin, and Kasuma (2017) and Mansor (2016) agreed that social media enhances the interactions between the students and teacher and further improves their learning experience.

\begin{tabular}{l|r|r|r|r|r} 
Descriptive Statistics & \multicolumn{1}{l}{} \\
\hline & $\mathrm{N}$ & Minimum & Maximum & Mean & Std. Deviation \\
\hline pre1 & 24 & .0 & 67.0 & 32.167 & 18.9224 \\
\hline post1 & 24 & 3.0 & 86.0 & 47.625 & 23.6198 \\
\hline pre2 & 24 & 13.0 & 100.0 & 53.042 & 23.5455 \\
\hline post2 & 24 & 25.0 & 100.0 & 72.917 & 22.2865 \\
\hline Valid N (listwise) & 24 & & & & \\
\hline
\end{tabular}

Table 3: Descriptive Result of Pre-tests and Post-tests

Overall, the results from Table 3 above indicate significant improvements between pre-test results and post-test results of the innovation. It summarizes the descriptive results of the pre-tests and post-tests for both topics. The data shows that the average scores for both post-tests $\left(M_{1}=\right.$ 47.63, $\mathrm{SD}_{1}=23.62$ and $\left.\mathrm{M}_{2}=72.92, \mathrm{SD}_{2}=22.29\right)$ were significantly higher than the pre-tests $\left(\mathrm{M}_{1}=\right.$ 32.17, $\mathrm{SD}_{1}=18.92$ and $\left.\mathrm{M}_{2}=53.04, \mathrm{SD}_{2}=3.55\right)$. This data suggests most of the participants have obtained improvements in the targeted topics during the post-tests.

Particularly, increases in performances are linked to the relationships between learning and development in the Zone of Proximal Development (ZPD) of the socio-cultural learning theory proposed by Vygotsky (1962). From the pre-tests results, teacher was aware of the learners' readiness level and had differentiated the instruction according to the learners' level. Teacher then provided instruction with the appropriate amount of guidance and support (Burkett, 2013) to encourage learner to work independently. In this study, these were implemented throughout the six sessions of "AsKINstagram" by which learners' answers were corrected and given immediate feedbacks. Consequently, during the post-tests, learners utilised their previous experiences during answering the "AsKINstagram" together with the knowledge attained in the classroom to answer the tests.

\section{CONCLUSION}

In this study, the findings reported have provided an insight into the intervention of social network, Instagram as an innovation to benefit not only the English language teachers but also pupils in primary school in experiencing virtual English language learning. Specifically, the researchers intend to utilise ASK feature on Instagram as one of the classroom interventions to promote conducive English language learning after school hours targeted a group of primary school pupils who are interested in Instagram more than other social networks like Facebook, Twitter and Blogs. The study itself aims to provide a virtual learning area that could improve students' performances in ESL writing. Methodologically, the intervention of ASK feature in ESL writing had proven to be useful and motivating as there is significant improvement in participants' performance in writing in English. In 
addition, the integration of ASK feature in ESL writing does help in maximizing students' participation in writing in English after school hours. It also shows that the integration could extend the participants' learning environment beyond their classroom setting.

Nonetheless, this study entails further investigation in other aspects of English language learning. For instance, even though ASK feature on Instagram revealed here might be significant to the success of teaching and learning of English language especially in writing lesson, they may be insignificant for other students in other schools, in different part of the country due to the accessibility of Internet connection and the availability of smartphones or tablets. A similar study conducted in secondary and tertiary levels would definitely provide different insight of the integration of Instagram in enhancing English language learning in all levels. On another angle, the present study could be prolonged by associating the integration of social network Instagram with students' perception in acquiring English language through social network. Besides that, for pupils in primary schools, feedback from parents in monitoring the learning via tablets or gadget could be profound for future research. Furthermore, a study demonstrating the interaction between strategies, motivation and achievement in English language teaching and learning shall provide greater understandings into which social network works superior with which group of learners.

Thus, this study shed some light in understanding the integration of social network employed by teachers in maximising students' participation in English language learning. Therefore, it is necessary for future studies to understand its potential impact towards students such as students' perception towards learning English through social networks in the effort to enhance both the teaching methods and also the acquisition of English language among learners. 
INTERNATIONAL JOURNAL OF ACADEMIC RESEARCH IN BUSINESS AND SOCIAL SCIENCES

Vol. 9, No. 1, Jan, 2019, E-ISSN: 2222-6990 @ 2019 HRMARS

\section{REFERENCES}

Adas, D., \& Bakir, A. (2013). Writing difficulties and new solutions: Blended learning as an approach to improve writing abilities. International Journal of Humanities and Social Science, 3(9), 254-266.

Akhiar, A., Mydin, A. A., \& Kasuma, S. A. A. (2017). Students' Perceptions and Attitudes Towards the Use of Instagram in English Language Writing. Malaysian Journal of Learning and Instruction (MJLI), Special issue on Graduate Students Research on Education, 47-72.

Alsamadani, H. A. (2010). The relationship between Saudi EFL students' writing competence, L1 writing proficiency, and self-regulation. European Journal of Social Sciences, 16(1), 53-64.

Al-Ali, S. (2014). Embracing the selfie craze: Exploring the possible use of Instagram as a language mLearning tool. Issues and Trends in Educational Technology, 2(2).

Bell, M. A. (2013). Picture this! Using Instagram with students. Internet@Schools, 20(4), 23-25.

Bidin, S., \& Ziden, A. A. (2013). Adoption and application of mobile learning in the education industry. Procedia-Social and Behavioral Sciences, 90, 720-729.

Burkett, J. A. (2013). Teacher perception on differentiated instruction and its influence on instructional practice. (Doctoral dissertation, Oklahoma State University).

Al Fadda, H. (2012). Difficulties in academic writing: From the perspective of King Saud university postgraduate students. English Language Teaching, 5(3), 123-130.

Gilakjani, A. P., Lai-Mei, L., \& Ismail, H. N. (2013). Teachers' use of technology and constructivism. International Journal of Modern Education and Computer Science, 5(4), 49.

Handayani, F. (2015). Instagram as a Teaching Tool? Really?. Proceedings of ISELT FBS Universitas Negeri Padang, 4(1), 320-327.

Hashim, H., Yunus, M. M., Embi, M. A., \& Ozir, N. A. M. (2017). Mobile-assisted Language Learning (MALL) for ESL Learners: A Review of Affordances and Constraints. Sains Humanika, 9(1-5).

Hashim, H., Yunus, M. M., \& Embi, M. A. (2018). Learning through Mobile: Exploring the Views of Polytechnic ESL Learners. Teaching and Learning English in Multicultural Contexts (TLEMC), 2(1).

Khalitova, L., \& Gimaletdinova, G. (2016). Mobile technologies in teaching English as a foreign language in higher education: A case study of using mobile application Instagram. In ICERI2016 Proceedings 9th International Conference of Education, Research and Innovation. Seville, Spain.

Lunden, I. (2014). Instagram Is the Fastest-Growing Social Site Globally, Mobile Devices Rule Over PCs For Access. TechCrunch, January 21.

Mansor, N., \& Rahim, N. A. (2017). Instagram in ESL Classroom. Man in India, 97(20), 107-114.

McBride, K. (2009). Social-networking sites in foreign language classes: Opportunities for re-creation.

The next generation: Social networking and online collaboration in foreign language learning, 8 , 35-58.

Mansor, N. (2016). Enhancing Communication Via Social Media in ESL Classroom. Paper presented at the 6th International Conference on Language, Education, and Innovation, Singapore.

Naismith, L., Lonsdale, P., Vavoula, G., \&Sharples, M. (2004). Mobile technologies and learning.

Nordin, N., Embi, M. A., \& Yunus, M. M. (2010). Mobile learning framework for lifelong learning. Procedia-Social and Behavioral Sciences, 7, 130-138.

Normaliza Abd Rahim (2014). Learning through Blog Writing: Embracing the Technology. Terengganu: Penerbit Universiti Malaysia Terengganu 
INTERNATIONAL JOURNAL OF ACADEMIC RESEARCH IN BUSINESS AND SOCIAL SCIENCES

Vol. 9, No. 1, Jan, 2019, E-ISSN: 2222-6990 (C) 2019 HRMARS

Pero Ali. (2014). Instagram in Learning English Language. from http://prezi.com/orhxy6Icpc8/instagram-in-learning-english-language/

Salomon, D. (2013). Moving on from Facebook Using Instagram to connect with undergraduates and engage in teaching and learning. College \& Research Libraries News, 74(8), 408-412.

Shafriri, Y., \& Levy, D. (2018). What are the Unique Characteristics of Integrating Mobile Applications in Learning? Journal of Interactive Learning Research, 29(3), 271-299.

Tekulve, N., \& Kelly, K. (2013). Worth 1,000 words: Using Instagram to engage library users. Brick and Click Libraries Symposium. Retrieved July 25, 2015 http://ecommons. udayton.edu/roesch_fac/20

Vie, S. (2008). Digital divide 2.0: "Generation M" and online social networking sites in the composition classroom. Computers and Composition, 25(1), 9-23.

Vygotsky, L. S. (1962). Language and thought. Massachusetts Institute of Technology Press, Ontario, Canada.

Warnock, S. (2009). Teaching writing online: How and why. Urbana, IL: National Council of Teachers of English (NCTE).

Wiktor, K. (2012) A Billion Dollar Idea: Instagram and Language Learning. Retrieved from http://bravelearning.com/2012/04/20/a-billion-dollar-idea-instagram-and-language-learning/

Yedla, S. (2013). MALL (mobile assisted language learning): A paradise for English language learners. Journal of English Language \& Translation Studies, 1(2), 91-99.

Yunus, M. M., Salehi, H., \& Chenzi, C. (2012). Integrating social networking tools into ESL writing classroom: Strengths and weaknesses. English Language Teaching, 5(8), 42.

Yunus, M. M., Nordin, N., Salehi, H., Sun, C. H., \& Embi, M. A. (2013). Pros and cons of using ICT in teaching ESL reading and writing. International education studies, 6(7), 119.

Zheng, B., Yim, S., \& Warschauer, M. (2018). Social media in the writing classroom and beyond. The TESOL Encyclopedia of English Language Teaching, 1-5.

Zaki, A. A., \& Yunus, M. M. (2015). Potential of mobile learning in teaching of ESL academic writing. English Language Teaching, 8(6), 11. 